\title{
WOMEN-SNIPERS FROM CHECHNYA TO UKRAINE: A POST-SOVIET WAR LEGEND
}

\author{
Amandine Regamey \\ University Paris I, France \\ CERCEC (EHESS / CNRS) \\ e-mail: amandine.regamey@gmail.com
}

\begin{abstract}
Among the rumours that circulated in the Russian army in Chechnya in the first decade of the twenty-first century, one of the most widespread involved women-snipers, former biathlon champions from the Baltic states, who allegedly fought alongside Chechen militants. More than ten years later, the rumour surfaced once again in Ukraine. This article explores the different aspects of a war legend that was born among soldiers, was embodied in fiction and popular culture, and used in official propaganda. It shows that the focus on Baltic mercenaries allows to present Russia simultaneously as the successor of the Soviet Union fighting against fascism, and as a state besieged by Islamic terrorism and American expansionism. The fact that women served as snipers in the Soviet army in the Second World War may give to the legend its particular post-Soviet characteristics, but the strength of the legend comes also from its embodying the fear of threatened masculinities. The conclusion reflects on the possible impact of the legend for civilians in areas torn by war, and on the ethical issue it raises for the researcher.
\end{abstract}

Keywords: Baltic states, Chechnya, masculinity, propaganda, Russia, snipers, Ukraine, war legend, women

Among the rumours that circulated in the Russian army in Chechnya, one of the most widespread involved women-snipers, former biathlon champions from the Baltic states, who allegedly fought alongside Chechen militants. Beginning in 1994, the so-called "White Tights" featured in media reports, in official political or military declarations, but also in films, books, and songs.

Twenty years after, Ukrainian Deputy Minister of Youth and Sports, a former Olympic champion in the Ukrainian women's biathlon team, was accused on Russian television of working as a sniper and killing civilians and children in the eastern Ukrainian town of Slavyansk. ${ }^{1}$ While she refuted these allegations as "part of Russian propaganda", she suggested that "perhaps these 'journalists' decided to recall this old story with the Baltic biathletes who allegedly fought in Chechnya". ${ }^{2}$ 
References to these so-called women-snipers have surfaced in all the conflicts of the post-Soviet space: Nagorno-Karabakh, Tajikistan, Transnistria, Abkhazia (Voronov 2004; Ianchenkov 2000). After the rumours of women snipers had surfaced in southern Ossetia in 2008, Russian journalist Oleg Panfilov declared that "these tales, these myths about White Stockings, about Negroes with guns - these are myths that date from the beginning of the 1990s. They were in Abkhazia, and Tajikistan, and in the Fergana Valley, and always, for some reason, these same sharpshooters from the Baltics in white tights, and Negroes, if I may say so". ${ }^{3}$

The impact of these legends on the ground is twofold. First, when a woman is arrested in or near the battlefield, regardless of the circumstances and of her real role in the army (cook, secretary, nurse, fighter), she is said to be a sniper. "If you are detained - that's it, you're a sniper," writes Russian journalist and former serviceman Arkady Babchenko, "even if you were just going to the market for potatoes. The fact that you are detained is already evidence" (Babchenko 2016). In 2001, General Gennady Troshev, head of the North Caucasus military district, explained in an interview that he had met women fighters during his military career and that "most of them were snipers". ${ }^{4}$ In Ukraine, when Ukrainian military pilot Nadezhda Savchenko was captured in June 2014 by pro-Russian separatists, she was accused on Russian television of being a "well-trained" sniper. ${ }^{5}$ After Ukrainian forces had arrested three women among separatist forces near Slavyansk, the anti-terrorist press centre claimed that "three female snipers surrendered". ${ }^{6}$ Particular media coverage is generally given to the capture of alleged women snipers. When more than a hundred fighters entrenched in the Chechen village of Komsomolskoe capitulated after heavy shelling in March 2000, Lenta.ru's main headline was: "In Komsomolskoe a woman-sniper surrendered". ${ }^{7}$

But there is also another consequence of these rumours: when soldiers are under enemy's sniper fire, they accuse these snipers of being specifically women. According to Russian general Gennady Troshev, at the beginning of the Second Chechen War, ${ }^{8}$ Chechen snipers were particularly active and dangerous and "in those sniper teams there were often women" (Troshev 2001). In a TSN newsreel on March 9, 2015, the Ukrainian journalist reporting about the everyday life of the Donbass battalion explains:

The men admit that here, on the frontline, they are less afraid of tanks or heavy artillery than of the enemy snipers. For this function, on the terrorist side, is carried out by girls. ${ }^{9}$

Stories about women-snipers did not only circulate in the context of post-Soviet local wars. The "Flintenweib", a cruel and sexually depraved woman with a gun, 
was a crucial figure among German Freikorps, who fought in the East after the First World War (Theweleit 1987). It was also central in the representations of German soldiers about the Soviet Army. Soon after the Normandy landings in 1944, allied corps also talked about French female sharpshooters, former mistresses of German soldiers: the rumour was so widespread that the military authorities had to issue an official denial (Beevor 2009: 179; Bourke 1999: 327-328). In Vietnam, where women fought among the Vietminh, American soldiers talked about the mythic "Apache", a sadistic woman-sniper, and the figure of the woman-sniper also features in fiction, such as Stanley Kubrick's Full Metal Jacket (1987). More recently, Turkish officials reported that Serbian mercenaries-snipers, including women, fought alongside Kurdish insurgents. ${ }^{10}$

So what is the specificity of this legend in the post-Soviet space? I will try to answer this question by exploring different aspects of the legend, after having defined what is meant here by "legend" (1). Born among soldiers, the womansniper legend was used in official propaganda (2): it was spread by fiction and popular culture, but echoed soldiers' experience in the field (3). The focus on-Baltic mercenaries allows to depict Russia as simultaneously waging war against fascism, Islamism, and America (4). The historical figures of Soviet female fighters may have given an additional impulse to the legend (5), but its strength comes also from the fact that it embodies the fears of threatened masculinities (6).

\section{LEGENDS AND THE QUESTION OF TRUTH}

Different sources have been used in this research: media articles, internet resources, videos, official declarations, but also fiction, books, and films. Some of them only mention the existence of female snipers, others report elaborated stories, some are clearly fiction while others are news reports. Why, then, use the term legend to unite such different stories?

While there is a growing body of literature on contemporary legends (Oring 1990, 2008; Dégh 1991, 1996; Bennett \& Smith 1996; Campion-Vincent \& Renard 2002; Bennett 2005; Fine \& Campion-Vincent \& Heath 2005; Bonhomme 2009; Fine \& Ellis 2010; etc.), there is still no consensus among researchers either on the term to be used (contemporary, modern or urban legends, myths, rumours, foaf tales, legendry, etc.) or on the exact definition of these legends. Nevertheless, researchers agree on some key aspects that can all be found in the stories about women-snipers mentioned in this paper.

First of all, a "legend is, or approximates, a narrative" (Oring 2008: 128). This criterion is usually used to differentiate legends from rumours: while 
"a rumour is merely a sort of plotless unverified report" (Baky 1994), legends can be defined as a kind of "solidified" rumour (Allport \& Postman 1947: 162), based on a much more constructed and structured narrative. Legends are "not something vague, diffuse and formless like a rumor [...] they are texts rather than shapeless bits of discourse", writes Gillian Bennett (2005: xii).

This difference is exemplified by Gary Fine and Bill Ellis when they explain that "a rumour often is a generalization, stating (for instance) that immigrants 'do' something, while a legend is a specific example, alleging that at a particular time and place immigrants 'did' or 'are about to do' something" (Fine \& Ellis 2010: 4). Indeed, stories about female snipers can be either rumours (which mention the presence of women-snipers among enemy soldiers in Abkhazia, Chechnya, Ukraine, etc.) or legends (which provide the name, details, and deeds of a particular woman). But Fine and Ellis also point out that "the boundaries between the two are hazy, however, and even folklorists and social scientists who study both find themselves hard put to draw a sharp boundary" (Fine \& Ellis 2010: 4). Rumours will thus be included in this case study together with legends, all the more because they often circulate and are transmitted in the same way.

While a rumour is often used as a synonym of "word of mouth", and a legend is said to have "at least part of its origins in oral transmission" (Baky 1994), Dégh and Vázsonyi are of the opinion that "telling, even in folklore, need not always be identical with talking. There are other forms of communication suitable for folklore materials" (Dégh \& Vázsonyi 1983: 5). They mention the increasing influence of mass media, telephone, car and plane travel, to which of course we should now add the Internet and social networks as crucial transmitters of rumours and legends.

The second crucial aspect of legends is their multiplicity. There is a general agreement that, to be called a legend, a story "must exist in more than two variations" (Baky 1994), that "contemporary legend is a type of discourse which (i) may be presented in a multiplicity of forms and media; (ii) exists in multiple versions over time and space" (Bennett \& Smith 1996: xxii) The fact that a story repeats over time, that it can be heard in different historical contexts, is precisely the first indication that it is a legend, but can explain also why legends often "accommodate traditional themes" (Baky 1994). Legends are "those stories that have been around long enough to be instantly recognizable, to have acquired a history, to echo folkloric themes and motifs" (Bennett 2005: xiii). As we will see further on (in the chapter about threatened masculinities), stories of female snipers do indeed incorporate traditional motifs and echo Russian folktales.

These folkloric themes and motifs may involve ghosts or mysterious phenomena, but contemporary legends are not always linked with the supernatural or the uncanny. More generally, "contemporary legend themes are broadly 
thematically related in that they project a dissonant world (iv) which may be bizarre or preternatural... (v) and/or which may involve either explicitly or by implication behaviour that has cultural restraints placed on it" (Bennett \& Smith 1996: xxii).

This third criterion, the notion of the "dissonant world", may be more difficult to identify in war legends because, by definition, these stories happen in a world of war which is already dissonant with the normal world. But all war legends involve, indeed, a behaviour that infringes not only cultural or social norms but also simply the "laws of war": government abandoning its soldiers on a desert island (Gulzow \& Mitchel 1980), soldiers trafficking in organs (Regamey $2012 \mathrm{~b}$ ) or women using arms and spilling blood in spite of an anthropological taboo (Héritier 1996).

Bennett and Smith note also that "the dissonance of the legend world, and the mismatch between it and the life circumstances of tellers and audiences, creates a possibility of (and maybe demand for) some form of active engagement with the legend" (Bennett \& Smith 1996: xxii). Indeed, a legend is not "just a story", and its fourth characteristic is that it engages, in one way or another, both the narrator and the listener. Legends can be told and passed on for a multiplicity of reasons: to illustrate a point, to demonstrate, to test the credibility, to boast of knowledge, to avoid openly expressing an opinion, etc. Whatever the reasons, "consensus has emerged among experts that the proper study of the so-called 'legend' or 'rumour' was not the infinitely varying narrative texts collected by observers, but rather the social process that generated them" (Fine \& Ellis 2010: 4).

Among the reasons why people transmit a rumour or a legend, the notion of belief has gradually been abandoned by researchers (Dégh 1996). Legends can be told, repeated, discussed, and transmitted even without any belief in their content.

We may not find a given story credible; that is, we may find the source of information dubious (and the use of the 'friend of a friend' as the authority has been noted for decades). However, many people will nevertheless discuss and pass on rumours because they contain a plausible claim. (Fine \& Ellis 2010: 5)

This question of credibility and plausibility leads us to the most discussed and controversial issue - the question of truth.

Legends are situated somewhere on a continuum between myth and folktale at one pole, and news and history at the other, moving along this continuum depending on the individual story and the whims or objectives of the individual storyteller who relates it. (Bennett 2005: xi) 
In each of these cases, their relation to the question of truth is different: newsreels or official declarations supposedly report about objective facts, while books and films can openly be fictional. But what unites them is the fact that "the scene is always set in the world as we know it, and the stories seem to be giving information about that world" (ibid.). War films, for example, even if they are based on a completely fictional scenario, pretend to represent the war as it is, to reflect it as faithfully as possible, and several films that feature womensnipers (see the chapter about the legend between popular culture and military experience) are based on historical events and feature historical characters (Chechen and Russian leaders, etc.).

So, on the one hand, legends circulate - if not as true stories - at least as plausible and credible stories. On the other hand, "the assumption that legends (and their cousins, rumours) are false is often implicit, merely an undercurrent to the researcher's work" (Bennett 2005: 304). There seem to be two ways for researchers to deal with this contradiction.

The first approach would be to consider that legends are true in some symbolic kind of way, like myths (ibid.: xi), that these "stories are repeated and circulated because they are true at that indeterminate level between fact and metaphor" (Scheper-Hughes 1996: 5). People may tell stories that are not an "accurate description of what they saw", because these stories nevertheless "carry the values and meanings that most forcibly get their point across" (White 2000: 30). Stories about organ trafficking that circulated in Chechnya in the 2000s conveyed, for example, the sense of horror, inhumanity, and physical destruction experience by Chechens during the war (Regamey 2012b). Rumours about women-snipers and mercenaries may be "true" for soldiers as far as they suggest that Russia is under treacherous attacks from the outside (see the chapter about Baltic mercenaries as enemies) and because they allow for an expression of fear for their virility (see the chapter about threatened masculinities).

Another approach to the question of truth is to consider that legends may be true or false, but that they are legends (or rumours) since they "lack any systematic means of authentication" (Baky 1994) or they "lack secure standards of evidence" (Fine \& Ellis 2010: 4). But this approach is challenged by the fact that legends do not only "make a claim about the truth of an event" (Oring 2008: 128) - they also use a specific rhetoric and different tropes to support these claims, and mobilise a "rhetoric of truth" (Oring 2008).

Indeed, different means are employed by those who report legends to suggest that these stories could be validated by "secured standards of evidence": reference to experts' opinion (physicians, the military), presentation of physical clues and logical proofs, etc. But even a perfunctory scrutiny allows us to see the 
faults in this rhetoric: hasty or over-generalisations, confusion between effects and causes, faulty syllogisms, inversed logical connections, etc.

By way of example, we can quote an interview with the separatist fighter who claims to have captured the Ukrainian military pilot Nadezhda Savchenko in June 2014. More than one year after her capture, he tries to convince the journalist that she was a sniper, by using different "means of authentication":

- But is Savchenko really a sniper?

- Of course. Do you think a helicopter aviator would get the call-sign 'Bullet'? No! Impossible. She could be.... whatever, but not 'Bullet'. Believe my combat experience, this call sign is chosen by sharpshooters or by snipers... - Are you sure? Did you question her, or what?

- I am not sure, I know. Why do I insist on that? Because when I went away with her, I took her personal belongings. A grey backpack with pink flowers, which contained a red civilian dress, black $V$-string panties and white sandals. Why should a helicopter pilot with the call-sign 'Bullet' be on the front line with civilian clothes? So as to be able, at the right time, to change clothes and go away. (Azar 2016)

As we will see further on, war legends may circulate among soldiers or be picked up by official propaganda - but in both cases they can still be "defined as a narrative performance that invokes a rhetoric of truth" (Oring 2008: 159).

\section{SOLDIERS' RUMOURS AND OFFICIAL PROPAGANDA}

In August 1914, rumours about Belgian "Francs-tireurs", armed civilians who treacherously attacked German soldiers, prompted German soldiers to commit violence against the civilian population in retaliation (Horne \& Kramer 2001). Fernand van Langenhove, who first investigated this rumour, suggested that it was born on the frontline and then spread to the rear: "Those legends that were told in letters from the front, were reprinted and multiplied by the press under control, they passed then in books, in the chronicles of war, in short stories, in popular literature and theatre" (Langenhove 1916: 235). They finally gained an official consecration in political statements. Relying on his experience on the front during the First World War, French historian Marc Bloch suggested also that rumours were mainly born among soldiers, and that they circulated via word-of-mouth between the front and the rear (Bloch 1999 [1921]).

The fact that these rumours come "from below" suggest that war legends are not just a synonym for propaganda or disinformation "from above". Indeed, 
"falsehood" can take "several different sorts of disguises", from the "deliberate official lie" and the "deliberate forgery" to "the general obsession, started by rumour and magnified by repetition and elaborated by hysteria, which at last gains general acceptance" (Ponsonby 1928). But whatever their origins, rumours are used by officials and state media to stigmatise the enemy and thus can be first investigated as a part of official propaganda.

The legend of women-snipers in Chechnya seems to have circulated following a logic quite similar to that described by Van Langehove. Rumours about the presence of "White Stockings", women mercenaries from the Baltic countries, circulated among Russian troops in Chechnya during the first war (1994-1996). By accrediting these rumours, military and political authorities spread them further and gave them an echo in the whole Russian society. Relying on official statements, the Russian media helped to spread these rumours, either by providing deliberately false information or by twisting the reality, using the slightest sign as "proof", publishing headlines disconnected with the article content, etc.

On January 18, 1995, during the battle for Grozny, an article in the daily Kommersant quoted a document from the "sources close to the border guard" to assert that several foreign mercenaries were fighting in Chechnya. According to this document, "the presence of mercenaries from the Baltic countries is substantiated by precise facts. In Grozny central districts, women-snipers, members of the organisation 'White Stocking' have been spotted" (Romashov 1995). On January 24, 1995, Russian army newspaper Krasnaya Zvezda as well as several TV channels reported that a platoon of "women-snipers from Estonia and other Baltic countries" was based in a flat at 4 Malgobek Street in Grozny. According to Russian journalist V. Voronov, it was a deliberate forgery: the media picked out a flat that was in fact the apartment of three women journalists. ${ }^{11}$

When the Second Chechen War began in August 1999, the same phenomenon could be observed. Chechen warlord Shamil Bassaev conducted a military raid in the neighbouring Dagestan Republic to support Islamic villages. On October 2, 1999, Russian newspaper Nezavisimaya Gazeta reported in an article titled "The White Tights fought in Dagestan" that three foreign sniper women fought alongside the Wahhabis and that according to the Ministry of Interior one was "a mercenary from the Baltic States" (Dargo 1999). On February 17, 2000, Russian spokesman Sergey Yastrzhembsky declared that "federal forces possess irrefutable evidence that women-snipers are fighting on the side of the militants". ${ }^{12}$ Yet, none of the information he gave on the three women showed that they were women fighters, let alone sharpshooters.

On February 14, 2000, Pervyi Kanal (First Channel) informed its audience about the arrest of two women who had been identified by the special services 
as snipers. One of the women was shown on TV: she was blindfolded, and the journalist zoomed in on her hands and on her face, while someone (supposedly a member of military intelligence) explained why she undoubtedly was a sniper:

The fact that the finger is bent and callous is the first sign. The second one: the light facial hair on the left side of the face can be quite clearly seen - while on the right side of the face the hair is rubbed out. ${ }^{13}$

This is not the only case where such flimsy proofs have been used. Another article about a woman arrested while leaving Grozny in 2000 specified that "investigators believe that wearing only one earring is an indirect indication that the woman is a sniper. It is more convenient to shoot. The second distinguishing feature is a bruise on the shoulder, made by the rifle butt". ${ }^{14}$ The parallel with the Amazons, who were said to cut one breast to bend their bows more easily, is obvious here.

There was a similar construction of the figure of the enemy sniper, with minor signs transformed into "evidence", in the case of the Ukrainian Deputy Minister of Youth and Sports, Olena Pidrushna (Elena Pidgrushnaia in Russian). On June 1, 2014, Konstantin Dolgov, one of the leaders of the Novorossiya Popular Front, accused her on the Russia-1 TV channel of killing civilians in the eastern Ukrainian town of Slavyansk. His main argument was that "her husband is a member of the ultranationalist fascist party in the Ukraine" and these kinds of pseudo-logical links (she is married to a nationalist so she is a nationalist; nationalists are fascists so she is a killer) - were also the main arguments used by such newspapers as the official Rossiyskaya Gazeta, when they wrote:

In view of her biography, Pidgrushnaia, native from Ternopol, could well have been found to be on the Karachun with a rifle in his hands. The thing is that Elena married a year ago a very active leader of the Ukrainian Nazis, Aleksey Kaida. [...] Besides, Pidgrushnaia herself has repeatedly demonstrated her support for Ukrainian 'national idea' (emphasis added). (Likhomanov 2014)

The circulation of this kind of so-called "information" is certainly accelerated and aggravated by some faults of the media themselves: systematic publication of official information, no cross-checking, sensational headlines that have very little to do with the content of the article, etc. In the case of the current "information war" in Ukraine, these kinds of practices can be found on both sides of the conflict. ${ }^{15}$

On the Ukrainian side, in January 2015, newspaper Ukrainska Pravda reported that "special forces of the SBU [Security Service of Ukraine] arrested 
a young woman who operated as a sniper and killed at least ten Ukrainian soldiers". ${ }^{16}$ Nevertheless, the only "proofs" provided both by the SBU and Ukrainska Pravda were in fact photographs of the young girl posing with weapons, and snapshots from her personal page on Vkontakte and in other social media. According to the Euromaidan Press release, "By her own admission, Anastasia stated that she has used several weapons, the automatic rifle RPK74 (Kalashnikov) and the anti-tank weapon, RPG-7"17 (emphasis added). This "avowal" is in fact an answer to an anonymous question on Sprashivai.ru (http://sprashivai.ru), an internet website dedicated to anonymous contacts and discussions online, the largest one in Russia and the Commonwealth of Independent States (CIS).

Articles from one online edition are usually copy-pasted from one website to another without further verification, and social media permit a faster circulation of rumours and legends through numerous reposting and sharing, and constitute virtual communities where state borders are blurred.

\section{LEGEND BETWEEN POPULAR CULTURE AND MILITARY EXPERIENCE}

However, if this kind of information circulates so easily, it is also because it is considered as a plausible piece of news that resonates with existing representations. We must indeed, at this stage, mention the role of culture in spreading the legend of women-snipers.

They are mentioned first of all in soldiers' songs, such as "Snaipersha" (Female Sniper) by Serhzant Agapov, ${ }^{18}$ about a 16-year-old sniper in the ruins of Grozny, or "Devushka-sniper" (Girl-sniper)19 by Igor Zhdamirov, a Russian Afghan veteran who came to eastern Ukraine to support the separatists. These songs are sung or listened to among soldiers, but they also find a larger audience through the Internet.

Some veterans also took to writing, and there are numerous novels on womensnipers on Artofwar.ru (http://artofwar.ru) or other websites. ${ }^{20}$ The figure of the Baltic sniper is also at the core of some popular war novels: Viper: The White Tights by Ivan Streltsov ${ }^{21}$ or The End of the Last Hour by successful detective writer Friedrich Neznansky, which features an ultranationalist and paramilitary association in Estonia, where women learn to shoot and fight. ${ }^{22}$ Thousands of copies of these novels were published, but the largest diffusion of the legendary figure of the Baltic mercenaries is certainly due to films, which are shown on Russian TV, broadcasted all over the former Soviet Union, distributed through DVD copies, and once again shared on social media (especially Vkontakte). 
Chistilishche (Purgatory, 1997) by Alexander Nevzorov reached $34 \%$ of the Moscow audience when it was shown on TV on March 23, 1998. ${ }^{23}$ It shows sadistic Baltic female sharpshooters fighting along with barbarous Afghan and African mercenaries against courageous but helpless young Russian soldiers. In Muzhskaia rabota (Men's work, 2001) by Tigran Keosaian, two Baltic women mercenaries are hired to fire upon an OSCE convoy. Proryv (Breakthrough, 2006) by Vitaly Lukin shows a blond sharpshooter fighting against Russians under the command of an Islamic mercenary.

In Blokpost (Checkpoint, 1999), A. Rogozhkin, a film director best known in Russia for his comedy films, depicts the life of soldiers based somewhere in the North Caucasus. In spite of the danger (they are threatened by a sniper) they try to enjoy life; they also use the sexual services of a simple-minded woman who her younger sister sells to the soldiers. In the end the viewer discovers that this younger sister is precisely the sniper, and understands why she always insisted on being paid in cartridges. The film combines two different story lines, on which the legend of women-snipers is usually built: 1 - soldiers are threatened by a sniper, they finally discover that this sniper is a woman (and take revenge); 2 - soldiers develop a relationship with a woman from a nearby village before they find out that she is a sniper.

In their studies on Belgian legends about "Francs-tireurs" during the First World War, Horne and Kramer (2001) show the crucial role of the cultural background in shaping the legend (memories of the previous war with France, literature, media). But they also insist on reconstructing soldiers' subjective experience, and show that the grip of the legend is stronger when the cultural background combines with a specific situation in the field. The "Franc-tireur" legend was also convincing for German soldiers in 1914 because they were confronted with new weapons, and could not determine where the shooting came from.

In post-Soviet conflicts, the woman-sniper seems also to crystallize the main fears of the soldiers on the ground. Post-Soviet conflicts are often mountain or urban guerrilla war, where soldiers hold checkpoints and are afraid of being targeted by a sniper; the problem of friendly fire, common to all armies in the word, certainly reinforces the fear of an enemy who seems to shoot out of nowhere.

In the cases when soldiers occupy part of their enemies' territory, the womansniper also embodies the hostile part of the civilian population, which the soldiers should distrust: the part that secretly supports the enemy and may, at any time, turn against the occupying army. The legend appears here as a form of popular military knowledge, of "military lore" (Barden \& Provo 1995): by repeating the legend, soldiers also exchange pieces of advice on how to behave in the field, what to be wary of. It contributes also to creating a figure of the enemy among the local population, the treacherous pacific/civilian (mirnaia) girl. 
It is indeed significant that the legend evolves with the changes in military warfare and adapts to specific situations. In Donbass, for example, soldiers are frequently under heavy artillery fire, and there is a widespread suspicion against navodchiki (spotters), civilians who are accused of helping the enemy by correcting their artillery fire. This fear leads to the creation of a new mythic figure, the sniper-spotter. Nadezhda Savchenko was thus presented on the Russian NTV channel as a "woman-sniper who adjusted fire during the combats". ${ }^{24}$ And the soldiers of the Ukrainian Donbass Battalion also mix the two notions:

These girls, they look like pacific civilians but in reality they select a point, and half of them adjust fire, and after that they work with sniper complex against our soldiers. ${ }^{25}$

Even if the meaning of a "sniper complex" is not very clear, the last quote reminds us of the way a legend can evolve: based on a long-existing storyline, the rumour takes new forms depending on the realities on the ground, and these new forms, in turn, may find some representations in popular culture.

\section{BALTIC MERCENARIES AS ENEMIES: ANTIFASCISM, ANTITERRORISM, ANTI-AMERICANISM}

As we have seen, legendary women-snipers in the post-Soviet space are often embodied in the figure of "White Tights" or "White Stockings", the Baltic mercenaries who fight against Russian or pro-Russian forces. These former biathlonists appear in films and popular novels, but are also regularly mentioned in the media and/or by politicians. For example, the official newspaper of the Russian army, Krasnaya Zvezda, is adamant that "during the first Chechen campaign, [Bassaev] created a special platoon, 'the White Tights', comprising mainly women-snipers from the Baltic states. Every day they were paid 1,000 US dollars, and 1,500 dollars for each Russian soldier they killed" (Astashkin 2003).

The figure of these Baltic snipers appeared regularly in Russia in the first decade of the twenty-first century. After the hostage-taking in a school in Beslan (North Ossetia) in September 2004, the website Lenta.ru stated that "the terrorists in Beslan were covered by Baltic snipers". Lenta.ru relied on the declaration of a witness who saw "a very tall man with a sniper rifle" who talked with a "Baltic accent", and a "young blond woman who held a rifle with a telescopic sight". ${ }^{26}$ 
Baltic mercenaries were also allegedly seen in South Ossetia in August 2008. The nationalist leader Vladimir Zhirinovsky, well known for his provocative declarations, thus stated in a radio interview:

Ukrainian nationalists went there, without having any right to do it. Baltic snipers went there. Perhaps we should also talk kindly with the Balts?! How many Russian soldiers did they kill in Chechnya! [...] The same with Ukraine: we have to take tough measures. ${ }^{27}$

This link between Baltic snipers and Ukrainian nationalists is not new. In My War, published in 2001, Russian general Gennady Troshev wrote about Ukrainian mercenaries from the nationalist group UNA-UNSO (Ukrainian National Assembly - Ukrainian People's Self-Defence) and noted that there were also "girl snipers from Poltava and Nikolaev" (Troshev 2001) together with Chechen fighters.

This figure of the female Baltic mercenary allows to embody the enemy and, in turn, to characterize the struggle of Russian and pro-Russian forces around two key narratives: the continuation of the struggle led by the USSR against fascism during the Second World War, and the fight against a powerful and globalized external enemy, Islamic terrorism and/or American expansionism.

The name "White Tights" first reminds of the white camouflage suits worn by Finnish soldiers, called "Belofiny" (White Finns) by the Soviets during the 1939-1940 Winter War. The memory of Finnish kukushki (cuckoos), snipers who moved on skis, hid in the forests, and inflicted heavy losses on Soviet soldiers, is still so present that the term is used to describe any enemy sniper. The nickname "White Tights" or "White Stockings" probably derives from the snipers' winter camouflage uniform. Indeed, protection suits are called " $z a$ shitnye chulki" (protective stockings), and a "belyi chulok" (white stocking) is also a white knitted tube used by snipers to hide the dark parts of their rifle in winter (Rasskazov 2001). The expression "belyi chulok" is used together with "belye kolgotki" as a nickname for women sniper mercenaries. ${ }^{28}$ But while the term "chulok" has several meanings, including the stockings worn by women, its synonym, kolgotki, is used only for women underwear. Thus, the more frequent use of "belye kolgotki" insists on the feminine dimension and suggest that those who wear them are women.

Secondly, Baltic mercenaries are also presented as the descendants of the "Forest Brothers" who fought against Soviet soldiers, as the granddaughters of Baltic fascists of the Second World War. In dominant representations in Russia, the Baltic countries and Ukraine are linked by a common hatred towards Russia, a common fascist past, and common historical collaboration with the Nazis. The 
memory of the Second World War is indeed crucial in Russian official discourse related to these countries: the scandal around the removal of a monument to the Soviet soldier in Estonia (2007), and the official denunciation of the parades of the former Latvian SS in Riga. In 2014 Moscow described the new Ukrainian government as fascist, while pro-Russian separatist fighters rallied around the St. George's ribbon, which in the recent years has become the symbol of the Russian victory in the Second World War.

Finally, the fact that there are mercenaries suggests that substantial sums of money are at stake, and that the enemies benefit from the support of an international-scale power, the Islamic terrorists or the United States.

During the second war in Chechnya, the alleged presence of mercenaries was supposed to prove that Russia was fighting against international Islamic terrorism. Sergei Filatov, head of the presidential administration under Yeltsin in the $1990 \mathrm{~s}$, explained that "there were, at one time, Ukrainian nationalists and female snipers from the Baltic states. Then the link was made with the Afghan factions and bin Laden". ${ }^{29}$

More recently, in Ukraine, the Americans and NATO have been pointed out. While NATO conducts joint exercises with the Ukrainian army, and the Americans and the British send military advisers, Moscow denounces the presence of US mercenaries fighting directly in eastern Ukraine.$^{30}$ From speculations about the presence of "private security companies", such as Blackwater, discussions shift to the presence of black Afro-American mercenaries. ${ }^{31}$ "And also, they say, Niggers have been seen," confessed a separatist militant to a Russian volunteer in the Donetsk People's Republic (DPR): “They are mercenaries fighting here... from the United States, and up there they would sell their own mother for money" (Maksakov 2014).

And, once again, when black mercenaries are discussed, women-snipers are not far away. According to the Secretary of the Security Council of the DPR, Aleksandr Khodakovsky, no mercenary has been captured yet because they usually serve in the rear and fire from a long distance. "But they did kill, yes! Including the Baltic women-snipers. They have been active on that side from the beginning of the conflict." 32

These accusations against the Americans and NATO date back to the Maidan manifestation in Kiev. Snipers were said to be responsible for the killings of February 2014, and since the beginning of the demonstrations rumours circulated among President Yanukovych's supporters about the presence of NATO or American snipers on the protesters' side. ${ }^{33}$ Moreover, there were suppositions that the "snipers who allegedly shot at 'people in the street' during the February 19-20 bloodshed in Kiev had also shot at the police" (Denber 2014) - to provoke the bloodshed and make the two parties in conflict act against each other. 
This kind of rumour is not new: in October 1993, when President Yeltsin had soldiers fire on the Russian Parliament, entrenched in the "White House", some White House defenders said to have seen snipers on the roof of the American Embassy. A witness also talked about a woman carrying a rifle with a telescopic sight on the upper floors of a building near the White House - which led the journalists to conclude that the rumours about the presence of the "White Tights", who already fought in Abkhazia and Transnistria, were not unfounded. ${ }^{34}$

Dmitry Rogozin, former representative of Russia to NATO and Deputy Prime Minister since 2011, suggests in his memoirs that a firing post could not have been placed on the roof of the American embassy without the US ambassador's knowing about it. Thus, he suggests that Americans are the "third force" who "covertly prompted the massacres, and caused an escalation between the two parties" (Rogozin 2010).

The same idea is voiced by a fighter from the pro-Russian separatist Vostok brigade, when he talks about the Ukrainian Special Forces with whom they were fighting:

Those were good guys there. It was the Kirovograd Special Forces. They are great soldiers [...] honour to them. But then mercenaries intervened. They fired against the guys of the Kirovograd Special Forces and they fired at us, Vostok. It was a repetition of the Kiev scenario, you see. That is, they shot at the Special Forces and shot at us, so that we would shoot at each other. ${ }^{35}$

\section{WOMEN IN THE ARMED FORCES: AN ADDITIONAL TRIGGER TO THE LEGEND}

To what extent may the legend of women-snipers be related to the presence of women in the military, and to the fact that some women have really served as snipers in the Soviet army?

As for contemporary Ukraine, there are a growing number of women in the armed forces and women are becoming more vocal about their right to serve together with men. ${ }^{36}$ No wonder then that Ukrainian media report about women-snipers in the army; yet, there seems to be a growing confusion, at least in media discourse, between the "shooter" and "sniper". A sniper is indeed a highly specialized military professional, a long-trained sharpshooter with specific camouflage skills, whose rifle is usually fitted with a telescopic sight, while the women who are presented as snipers have in fact a very short military training. 
We could mention in this context, for example, a TSN News report about a girl-sniper from the Donbass battalion, a 23-year-old hairdresser-visagiste who became a sniper.$^{37}$ However, we learn from the same TSN report that before the war she had never touched a weapon - which makes it very unlikely that she became a sniper in a few weeks. Similarly, even if we lack sociological studies on women in the armed groups of the Donetsk and Lugansk Popular Republics (DNR/LNR), we can assume that very few of them have actually been trained to use weapons - not to mention being elite shooters. Tatiana Demchenko, the leader of the DNR women battalion, admitted, for example, that "the vast majority of women had never had a weapon in their hands before joining the militia" (Melnikov 2014).

The word "sniper" thus seems to be increasingly used as a synonym for "shooter", or even for "rifleman". This confusion may come from the double meaning of the Russian world strelok. Strelok can indeed be translated simply as "a soldier with a rifle", strelkovaia chast' being an infantry unit. At the same time, in the 1930 s, the best shooters trained by the Soviet paramilitary organisation OSOAVIAKhIM (Union of Societies of Assistance to Defence and Aviation-Chemical Construction of the USSR) were decorated with the medal of Voroshilovskii strelok (named after the People's Commissar for Defence, Klim Voroshilov) - in this case, strelok was indeed a synonym for "sharpshooter".

There were men and also women among the snipers trained in the Soviet Union in the 1930s, some of whom fought during the Second World War. The most famous is undoubtedly Lyudmila Pavlichenko, who took part in the battles of Odessa and Sebastopol in 1941-1942 and was credited with 309 kills, the highest score for a woman-sniper. She is still a well-known figure nowadays, especially after the release of a Russian-Ukrainian film Nezlamna (Indestructible), based on her biography, in March 2015. In Ukraine, references to Pavlichenko are made by both sides of the conflict; she is compared to the Ukrainian pilot Nadia Savchenko, ${ }^{38}$ while her photograph circulates in pro-separatist social networks with the caption: "Rambo? No, never heard. Lyudmila Pavlichenko, 309 dead fascists". ${ }^{39}$

While 800,000 women served in the Red Army in different capacities (nurses, auxiliaries, etc.), in 1943 a Central Women Snipers School was established in Moscow to train women for the front. These circumstances, as well as Soviet propaganda around women snipers, probably fuelled the rumours inside the German army at that time. There is, in fact, a huge gap between the real number of women-snipers and the pervasiveness of this representation among Wehrmacht soldiers: no more than 2000 women were trained at the Central Women Sniper School during the war. But the rumour also relied on other factors: the imagery of cruel and depraved Red women with guns, the "Flintenweib" (Freytag 2002), 
the fact that even nurses and orderlies carried guns, etc. Here, the legend was certainly fuelled by the vision of Red Army female soldiers, but this representation, distorted and magnified, found a fertile ground in an imagery already formed by pre-existing rumours and fiction (Theweleit 1987).

But what about the post-Soviet imagery of women-snipers? To what extent can it be influenced by the historical experience of Soviet women-snipers? My hypothesis is that the legend is based on an inversion: the features and characteristics that are specific to one's own army are attributed to that of the enemy. This inversion is possible in the post-Soviet space, because the enemy is perceived as very close and very similar.

Indeed, in most of the wars of the post-Soviet space, the enemy was once "one of us": it was very often a former neighbour, who grew up during the Soviet period. In "Devushka-sniper", Igor Zhdamirov sings about a soldier who leaves "to fight against a former brother / he's got the same automatic rifle / and swears in Russian just like us". This similarity allows for transposing the figure of the woman-sniper from one's own past and practices to that of the enemy. This transfer can be done only if the opposing society is perceived as sufficiently similar: there are, to my knowledge, no rumours about Afghan women-snipers, Afghan society being perceived as ultra-traditional. ${ }^{40}$

Thus, it is possible to imagine women-snipers in the opposing army because there were female snipers in one's own historical experience. The knowledge of this historical experience relies mainly on Soviet official memories and Soviet/ Russian films. So the imagery of women-snipers is in fact built on a process of permanent swinging to and from historical reality to fiction.

The vocabulary used by fictional contemporary women-snipers imitates the expressions of the Second World War, such as "going on a hunt" - meaning lying in wait. ${ }^{41}$ More generally, the practices of the fictional "White Stockings" reflect, as in a distorted mirror, the exploits of Soviet snipers: some practices of Soviet sniper women are distorted and ascribed to their fictitious homologues, and, in turn, these fictional practices are imputed to the Soviet women-snipers.

The White Tights are, for example, accused of marking their number of kills on their rifle butts, like the woman "with an SVD sniper rifle, produced in Russia, the butt of which had about a dozen notches. This sniper, who had an Estonian passport, admitted that this was her way of counting the number of soldiers she had killed" (Ianchenkov 2004). This alleged practice can be traced back to the Second World War. The number of enemies a sniper had eliminated was indeed precisely calculated, and the most successful snipers did receive a personal rifle. The account was officially kept in the military booklet of the "sniper, exterminator of fascists", but it could be also kept by snipers themselves. Thus, the Soviet documentary film Chernomortsy (1942), dedicated to 
Sebastopol defenders, shows a sniper "keeping his own account" by making marks with a knife on the root of a tree, in his trench. ${ }^{42}$

Lyudmila Pavlichenko also features in this film, and the operator insisted on filming her among the blossoms of a tree in flower, as a tribute to her femininity (Begunova 2014: 108-109). In another context, namely during a trip to the United States in 1942, to appeal to the American people, the representation of her femininity focused on her make-up and especially on the nail polish that decorated her "trigger finger" ${ }^{43}$ In turn, this focus on nails as a symbol of femininity is used and reverted in the representations of contemporary womensnipers:

On June 24, in Bendery a sniper was arrested, a mercenary from Lithuania, on whose account there were 33 victims. She used to make the notches on the butt of her rifle... with a nail file. (Medvedev n.d.)

Keeping count of their victims with cruel pleasure, women-snipers are also said to take fun in killing their victims slowly, like in Nevzorov's Chistilishche, where they gradually wound and mutilate soldiers before killing them. In Fatima, Russian writer Scherbakov pictures a sniper who gets sexually aroused when killing:

She made fun of her victims, playing with them. She drove alternately a bullet into each limb of the soldiers, and when they could no longer move or crawl, the fifth shot put an end to their life. (Shcherbakov n.d.)

A virtually identical scene can be found in S. Mokritskiy's recent film on L. Pavlichenko, in which, to impress her new partner, she plays with a German soldier and wounds him twice before finally killing him. ${ }^{44}$ So we can see how the legend finally influences the current representations of the Soviet women-snipers.

\section{THREATENED MASCULINITIES}

In a 2001 article about snipers in Chechnya, a Russian journalist quoted the alleged threats of a woman-sniper Masha to her future victims:

I'm going to kill you slowly, because I love it. I will first shoot you in the leg, I promise to aim at the kneecap. Then the hand. Then your balls. (Maetnaia 2001)

As an additional form of "refinement", the White Tights are said to take specific pleasure in shooting soldiers in their reproductive organs. On March 31, 2001, a Russian information website indicated that a Tajik woman-sniper was 
captured and killed after she advised soldiers by radio to "protect their private parts". ${ }^{45}$ This rumour is still alive, and thirteen years later, an eastern Ukrainian separatist fighter declares after the combats around Grozny Airport:

Snipers were chicks. We liquidated two of them, one by sniper fire, the other with a RPO, a flame-thrower. By the way, one of our fighters, he's a 300th [injured], he was shot in the inner part of the thigh, she aimed at his groin. ${ }^{46}$

More often than not, there is a second part to this legend: in Chechnya, it was said among Russian servicemen that women-snipers who castrated soldiers must be raped in retaliation and "exploded" by putting a gun or a grenade in their vagina. There were numerous stories about a Baltic biathlonist Milita Trankautene, who "cynically castrated young Russian officers with her precise shots", and who was "dropped from a helicopter by wounded paratroopers with a grenade in the vagina" (Maetnaia 2001). Aleksandr Krylov, who fought as a volunteer in Transnistria, admits that he had heard this story several times:

Well, the story of how the 'bitch-sniper' with a grenade shoved between the legs is thrown out of the windows of a multi-storey building - I have heard it from almost all participants in the so-called 'local conflicts', which took place during the past ten years on the territory of Russia, the former Soviet Union, and Eastern Europe. Well, of course with variations - concerning mainly the countries and the cities where, supposedly, these events took place, as well as the number of floors of the building where the execution was carried out. (Krylov 1999)

There seem to be several layers of interpretations to this aspect of the legend. First, we should remember the specific erotic connotations of a woman with a gun. In army folklore, the gun is very often compared with the soldier's girlfriend, like in this army proverb: "A rifle loves to be cuddled, cleaned, and lubricated" (Vintovka liubit lasku, chistku i smazku). The slang term "dvustvolka" refers not only to a double barrel rifle, but also to a woman who has sexual relations with two men at a time, a prostitute or simply a woman. ${ }^{47}$ But even more than sexual desire, the legend seems to refer to the castration complex, which Marie Bonaparte mentions in her analysis of war myths (Bonaparte 1946: 106-107). In this regard, two research directions seem particularly fruitful to explain the legend and its post-Soviet specificities: the accommodation of traditional themes and the fear of losing one's virility.

The theme of the dangerous woman who deprives the man of his virility can be traced back to the traditional vagina dentata folktales - a recurring motif in the mythologies of the world. The vagina that imprisons a man, severs his 
penis, and swallows it, is also the symbol of annihilation, of nothingness, as suggested by this Russian riddle: "What is not and will never be, and if it did exist nothing would exist? - A pussy with teeth". The same motive can be found in the Vietnam War stories about Vietnamese prostitutes who put Coke bottles in their vagina to emasculate American GIs (Barden \& Provo 1995). It appeared then as an expression of the fear of venereal diseases, and we can also mention here the American Army posters of the 1940s, which warned soldiers against the "juke joint sniper: syphilis and gonorrhoea" (Keneally 2011).

Traditional themes can also be seen in the punishment of the woman-sniper. The stories in which the women-snipers are pulverized and scattered in the wind evoke Russian traditional tales where the witch is torn to pieces, like in the White Duck:

The birds came flying up, and they pecked the flesh; the winds swept up, and they bore off the bones. And nothing was left of the wicked witch, neither trace nor word nor memory. ${ }^{48}$

When a Russian soldier says that he saw "how a woman-sniper was attached to an armoured vehicle and hauled on the road till all her flesh was torn", ${ }^{49}$ his story resembles very closely the end of the folktale "Sister Alyonushka and Brother Ivanushka", when "the wicked witch was tied to a horse's tail and the horse turned loose in an open field". The parallel between witches and womensnipers is even explicit in the story of a veteran of the 1994-1996 Chechen War, who recalls the execution of a Latvian sniper: "First, like a witch, she was nailed to the ground with stakes. Then she was crushed by an armoured car" (Belibentsev 2006).

The second theme in the story of the castrating woman-sniper and her punishment is the fear of losing one's manliness. This virility angst is not unique to post-Soviet fighters: everywhere "soldiers traumatised by war suffer from erection problems or premature ejaculation" (Le Naour 2007: 74). In addition, soldiers in the field are afraid of adultery, lest the women they leave for long periods may deceive them. Women-snipers also embody this fear of women's treason, which explains why in certain articles ${ }^{50}$ or songs they are Russian: for instance, in Igor Zhdamirov's song "Devushka-sniper" a young man dies from a bullet of his former girlfriend.

This fear of "not being a man any more" after the war is further aggravated by the post-Soviet context. Indeed, in many post-Soviet countries, the economic crisis of the 1990s did hit hard on men, who could no longer play their role of a "breadwinner" (Hohman 2015). The army, in representations still associated with manhood and courage, was not in a better condition: antiquated weaponry, dilapidated housing, low wages, and belated pay (Sieca-Kozlowski 2008). 


\section{CONCLUSION}

What can ultimately be the effects of this legend on the war field in various post-Soviet war contexts? The question deserves to be asked, since we have seen that the mythic figure of the "woman-sniper" sheds suspicion on female civilians in the conflict zone; it puts also servicewomen at a specific risk of being subjected to retaliation when captured.

There is undoubtedly a link between representation and violence (Horne \& Kramer 2001; Semelin 2002), even if other factors may be more central in explaining extreme violence (sudden de-socialisation and resocialisation in a violent group, incentives from the state or the media, sense of impunity, "moral holiday" or "forward panic" (Collins 2009; etc.). Moreover, the issue of sexual violence is particularly acute, since, as we have seen above, one of the punishments administered on the woman-sniper is rape.

In Chechnya, the legend was used as a justification for violence in the socalled Budanov case. Colonel Budanov, who abducted, raped, and killed a young woman in March 2000, built his entire defence in court on the allegation that she was a sniper, that she had killed his men, and that he had lost control of himself while questioning her (Regamey 2008, 2012a). But while the legend is used as a justification a posteriori, can we assume that it also plays a role a priori, in sparking or triggering violence?

In Chechnya, women were arrested on suspicion of being snipers, and became the inmates of a detention system where cases of rape and ill-treatment were widespread. In Ukraine, a former fighter of the Ukrainian Aidar battalion mentioned in an interview, among other cases of violence he witnessed at the front, the rape of women prisoners:

I once heard myself how one of the prisoners was raped. [...] Afterwards, I asked who this woman was. 'Oh, it's a separatist sniper.' - 'And how do we know? Did we take her with a weapon in hand?' - 'No, we found a balaclava among her things.' And so this woman, just because she had a balaclava, was taken to prison, where she was raped.(Chapai 2015)

On the separatist side, in the Donetsk People's Republic, the legend seems to have the same tragic consequences:

A volunteer from Kyiv, whose name cannot be made public, was working for an association distributing humanitarian aid in conflict affected areas. She was kidnapped on 12 June 2015 [...] by the DPR's MGB (Ministry of State Security) and accused of being a sniper belonging to the Pravyi Sektor (Extreme right pro-Ukrainian group). She was beaten and tortured even 
after MGB found that she is pregnant. She spent approximately 2 months in captivity and was released in August 2015. (FIDH/CCL 2015: 27)

Faced with these facts, the question of the responsibility of the researcher arises. To my opinion, the consequences of the legend of women-snipers require not only studying the multiple narratives and their "rhetoric of truth", but also showing its fallacy and "deconstructing" it whenever and wherever possible.

\section{NOTES}

1 Feik: ukrainskaia biatlonistka Elena Pidgrushnaia ubivaet detei v Slavianske (Fake: Ukrainian biathlonist Elena Pidgrushnaia is killing children in Slaviansk). Stopfake. org, June 2, 2014. Available at http://www.stopfake.org/fejk-ukrainskaya-biatlonistkaelena-pidgrushnaya-ubivaet-detej-v-slavyanske/, last accessed on May 31, 2017.

2 Ukrainskuiu olimpiiskuiu chempionku v Rossii schitaiut snaiperom ATO (In Russia, Ukrainian Olympic champion thought to be a sniper in the anti-terrorist operation). Obozrevatel', June 1, 2014. Available at http://sport.obozrevatel.com/sport/71963ukrainskuyu-olimpijskuyu-chempionku-v-rossii-schitayut-snajperom-ato.htm, last accessed on May 31, 2017.

3 Interview with Oleg Panfilov on Radio Svoboda, April 29, 2009. Transcript available at http://www.svobodanews.ru/content/transcript/1618827.html, last accessed on May 31, 2017.

4 Interview with General Troshev in Rossiiskaia Gazeta, March 28, 2001 (http://www. rg.ru/interview/543.shtm, no longer available).

5 Zhenshchina-snaiper rasskazala o napadenii na rossiiskikh zhurnalistov (Womansniper told about the attack on Russian journalists). NTV.ru, June 17, 2014. Available at http://www.ntv.ru/video/870600/, last accessed on May 31, 2017.

6 Na gore Karachun sily ATO plenili trekh zhenshchin-snaiperov (On Karachun Hill anti-terrorist troops captured three women-snipers). July 5, 2014. Available at http:// www.0629.com.ua/news/569786. Vo vremia boia na Karachune tri zhenshchinysnaipera sdalis' v plen silam ATO (During the battle on Karachun, three women-snipers surrendered to anti-terrorist forces). July 5, 2014. Available at http://obozrevatel.com/ politics/62140-vo-vremya-boya-na-karachune-tri-zhenschinyi-snajpera-sdalis-v-plensilam-ato.htm, both last accessed on May 31, 2017.

7 V Komsomol'skom sdalas' v plen zhenshchina-snaiper. Lenta.ru, March 24, 2000. Available at http://lenta.ru/vojna/2000/03/24/komsomolskoe/, last accessed on May $31,2017$.

8 The war during the period of 1999-2009. The campaign ended the de facto independence of the Chechen Republic of Ichkeria and restored Russian federal control over the territory (see https://en.wikipedia.org/wiki/Second_Chechen_War, last accessed on July 13, 2017). 
9 Shturmom namagalisia vziati boioviki s'ogodni selishche Shirokine (Today insurgents tried to seize Shirokine village). TSN News, March 9, 2015. Available at http://tsn.ua/ video/video-novini/shturmom-namagalisya-vzyati-boyoviki-sogodni-selische-shirokine. html, last accessed on May 31, 2017.

${ }^{10}$ One Serbian PKK sniper killed, another captured in Turkey's southeast. Hurriyet Daily News, February 2, 2016. Available at http://www.hurriyetdailynews.com/oneserbian-pkk-sniper-killed-another-captured-in-turkeys-southeast.aspx?PageID=238\& NID=94639\&NewsCatID=509, last accessed on May 31, 2017.

${ }^{11}$ See http://www.evartist.narod.ru/text1/81.htm\#\%D0\%B7_17, last accessed on July 10, 2017.

${ }^{12} \mathrm{~V}$ Chechne arestovany tri zhenshchiny-snaipera (Three female snipers arrested in Chechenia). Lenta.ru, February 17, 2000. Available at http://lenta.ru/vojna/2000/02/17/ sniper/, last accessed on June 1, 2017.

${ }^{13}$ Dlia zhitelei Groznogo zakryt svobodnyi prokhod v gorod. Na vykhode iz goroda zaderzhana zhenshchina-snaiper (Free access to Grozny is closed to its inhabitants. On the town's edge a woman-sniper was arrested). Pervyi Kanal, February 14, 2000. Available at http://www.1tv.ru/news/2000-02-14/, last accessed on June 1, 2017.

${ }^{14}$ Snaipersha Anna: Moloduiu moskvichku obuchali ubivat' rossiiskikh soldat v lagere Khattaba (Sniper Anna: How a young Moscow girl learnt to kill Russian soldiers in Khattab camps). Komsomolskaia Pravda, August 9, 2001. Available at http://www. kp.ru/daily/22608/9606/, last accessed on June 1, 2017.

${ }^{15}$ A recent hoax set up by journalism students (about the revival of a mythical TV series) has shown serious flaws in the work of some Ukrainian media outlets. Not only was the dubious information based on a single Facebook page, but it was also broadcasted without any verifications of the facts (see Anna Shamanska's "Old Dog, New Trick: 'Inspector Rex' Hoax Shows Ukrainian Journos' Gullibility”, RFE / RL, February 15, 2016. Available at http://www.rferl.org/content/ukraine-student-hoaz-shows-mediagullibility/27553928.html, last accessed on June 1, 2017).

${ }^{16} \mathrm{Na}$ Donbasi spetspriznachentsi zatrimali 19-richnu snaiperku (In Donbas, special forces arrested a 19-year-old sniper). January 12, 2015. Available at http://www. pravda.com.ua/news/2015/01/12/7054778/, last accessed on June 1, 2017.

${ }^{17}$ Ukraine's Security Service captured a 19-year-old terrorist sniper. Euromaidan Press, January 15, 2015. Available at http://euromaidanpress.com/2015/01/15/ukrainessecurity-service-captured-a-19-year-old-terrorist-sniper/, last accessed on June 1, 2017.

18 Text available at http://pesen.ru/publ/206-1-0-295; audio version available at http:// mp3-pesni.net, both last accessed on June 1, 2017.

${ }^{19}$ Text available at http://pesenok.ru/9/Igor-Jdamirov/tekst-pesni-Devochka-snayper; audio version available at https://www.youtube.com/watch?v=4T-xVZQgTpk, both last accessed on June 1, 2017. See also "Pesnia pro snaipershu" (Song about a female sniper), available at https://my.mail.ru/mail/baldin.anatolii/video/369/2087.html, last accessed on June 1, 2017. 
${ }^{20}$ See Solnechnyi udar (Sunstroke) by D. Linchevsky (http://artofwar.ru///inchewskij_d_i/ text_0070.shtml) or Fatima by S. Scherbakov (http://artofwar.ru/s/sherbakow_s_a/ fatimadoc.shtml). See also Kontrol'nyi vystrel (Test shot) by Afghan and Chechen veteran Nikolai Ivanov (http://rospisatel.ru/ivanov-kontrolny\%20vistrel.htm), all last accessed on June 1, 2017.

${ }^{21}$ Giurza: 'Belye kolgotki'. Eksmo-press 2003 (7,000 copies); republished in 2005 under the title Istrebitel' snaiperov (Sniper exterminator) in 15,000 copies.

${ }^{22} \mathrm{Na}$ iskhode poslednego chasa. Moscow: AST, 2002, published in thousands of copies, several reprints. Available at http://webreading.ru/det_/detective/fridrih-neznanskiyna-ishode-poslednego-chasa.html\#, last accessed on June 1, 2017.

${ }^{23}$ Moskovskaia auditoriia fil'ma Aleksandra Nevzorova "Chistilishche" (Moscow cinema audience of Chistilishche (Purgatory) by Alexander Nevzorov). FOM, April 9, 1998. Available at http://bd.fom.ru/report/cat/smi_tv/tvfilm/of19981406, last accessed on June 2, 2017.

${ }^{24}$ Zhenshchina-snaiper rasskazal o napadenii na rossiiskikh zhurnalistov (Woman-sniper told about the attack on Russian journalists). NTV.ru, June 17, 2014. Available at http://www.ntv.ru/video/870600/, last accessed on June 2, 2017.

${ }^{25}$ Shturmom namagalisia vziati boioviki s'ogodni selishche Shirokine (Insurgents tried today to seize Shirokine village). TSN.ua, March 9, 2015. Available at http://tsn.ua/ video/video-novini/shturmom-namagalisya-vzyati-boyoviki-sogodni-selische-shirokine. html, last accessed on June 2, 2017.

${ }^{26}$ Beslanskikh terroristov prikryvali pribaltiiskie snaipery (Beslan terrorist were covered by Baltic snipers). Lenta.ru, June 7, 2006. Available at http://www.lenta.ru/ news/2006/06/07/beslan/, last accessed on June 2, 2017.

${ }^{27}$ Interview with Vladimir Zhirinovsky on radio channel Ekho Moskvy (Echo of Moscow), August 11, 2008. Available at http://www.echo.msk.ru/programs/razvorotmorning/533185-echo.phtml, last accessed on June 2, 2017.

${ }^{28}$ See Neraskrytye tainy: Sushchestvoval li otriad snaipersh "Belyi chulok"? (Undisclosed secrets: Was there a White Tights sniper squad?) Documentary published on YouTube on March 15, 2014, produced by Moscow channel Doverie (Trust). Available at https:// www.youtube.com/watch?v=E-Ap7SqPFzo, last accessed on June 2, 2017; see also Russian Wikipedia page "Belye kolgotki".

${ }^{29}$ Sergei Filatov: Dudaeva podobrala Moskva (Sergei Filatov: Dudaev was chosen by Moscow). BBC interview, December 8, 2004. Available at http://news.bbc.co.uk/go/pr/ fr/-/hi/russian/russia/newsid_4079000/4079537.stm, last accessed on June 2, 2017.

${ }^{30}$ See, for example, Damien Gayle, "Has Blackwater been deployed to Ukraine?". Daily Mail, March 8, 2014. Available at http://www.dailymail.co.uk/news/article-2576490/ Are-Blackwater-active-Ukraine-Videos-spark-talk-U-S-mercenary-outfit-deployedDonetsk.html, last accessed on June 2, 2017. 
${ }^{31}$ Nigerian Mechanics Were Turned into "American Mercenaries and Chastisers" Who Had Come to Ukraine in Order to Fight Here. Stopfake, November 23, 2014. Available at http://www.stopfake.org/en/nigerian-mechanics-were-turned-into-americanmercenaries-and-chastisers-who-had-come-to-ukraine-in-order-to-fight-here/, last accessed on June 2, 2017.

${ }^{32}$ Nam nuzhna vsia Ukraina! (We need the whole of Ukraine!) Interview with the DPR Secretary of the Security Council of the DPR, Aleksandr Khodakovsky. Lenta.ru, March 30, 2015. Available at http://m.lenta.ru/articles/2015/03/30/khodakovskiy/, last accessed on June 12, 2017.

${ }^{33}$ NATOvskii snaiper-naemnik mog zastrelit' odnogo iz demonstrantov v Kieve (NATO sniper-mercenary could have shot a demonstrator in Kiev). January 23, 2014 (http://msk.mr7.ru/society/news/natovskiy-snayper-naemnik-mog-zastrelit-odnogoiz--1059552, last accessed on January 23, 2014; no longer available).

${ }^{34}$ Belye piatna chernogo oktiabria 93-go (The blind spots of black October). Moskovskii Komsomolets, October 3, 2003. Available at http://www.compromat.ru/page_13683. htm, last accessed on June 12, 2017. See also Amandine Regamey's "Le sniper sur le toit: Une rumeur d'octobre 1993", November 11, 2013. Available at http://russie. hypotheses.org/1342, last accessed on July 12, 2017.

${ }^{35}$ Opolchenets: Zhenshchiny-snaipery u aeroporta v Donetske streliali nashim v pakh (Militiaman: Women-snipers around Donetsk airport aimed at our groins). Life.ru, May 31, 2014. Available at http://lifenews.ru/news/134208, last accessed on June 12, 2017.

${ }^{36}$ See, for example, T. Martsenyuk \& G. Grytsenko \& A. Kvit (2016) "Invisible Battalion": Women's Participation in ATO Military Operations (Sociological Research). Available at http://www2.unwomen.org/-/media/field\%20office\%20eca/attachments/publications/ country/ukraine/invisible\%20batallion\%20study_eng_full.pdf?vs=2734, last accessed on June 12, 2017.

${ }^{37}$ Devushka-snaiper iz batal'ona 'Donbass': Poniala, chto ia na voine, kogda pogib nash boets (Girl-sniper from the 'Donbass' Battalion: I understood that I am at war when one of our soldiers fell). TSN News, September 21, 2014. Available at http://ru.tsn. ua/ukrayina/devushka-snayper-iz-batalona-donbass-ponyala-chto-ya-na-voyne-kogdapogib-nash-boec-387745.html, last accessed on June 13, 2017.

${ }^{38}$ Porazitel'naia skhozhest' Savchenko s legendarnoi ukrainkoi Pavlichenko shokirovala internet (The incredible similarity between Savchenko and legendary Ukrainian Pavlichenko shocked the Internet). Obozrevatel, April 22, 2015. Available at http:// obozrevatel.com/chronics/72916-porazitelnaya-shozhest-savchenko-s-legendarnojukrainkoj-pavlichenko-shokirovala-internet.htm, last accessed on June 13, 2017.

${ }^{39}$ Posted on September 10, 2015, on the Vkontakte account http://vk.com/love_separa.

${ }^{40}$ As a Muslim society, Chechen society is indeed also perceived as traditional, which can give an additional explanation to the focus on Baltic women-snipers, because Baltic societies are perceived as European ones. 
${ }^{41}$ See, for example, the testimonies on http://iremember.ru/memoirs/snayperi/, last accessed on June 13, 2017.

${ }^{42}$ Documentary film Chernomortsy (Black Sea fleet) by V. Beliaev (1942), available at http://www.net-film.ru/film-20435/, last accessed on June 13, 2017.

43 "The trigger finger of the Red Army girl sniper, credited by the Soviet military authorities with the death of 309 Germans, today was decorated with 'bright silk' nail polish", wrote the Philadelphia Inquirer on September 3, 1942. See also her description in The Baltimore News Post (September 10, 1942), "Wearing lipstick and bright pink nail polish", in Chicago News on September 26, 1942 ("On her nails, for the first time, she wore red polish"), and the headline of The Fresno Bee, on October 8 , 1942: "Tinted nails belie grim courage of Red girl sniper". All press clippings from the file about her trip in the USA can be found in the RGASPI (Rossiiskii gosudarstvennyi arkhiv sotsial'no-politicheskoi istorii (Russian State Archive of Socio-Political History)) in Moscow (fond 7M opis 2 ed khr 952).

${ }^{44}$ Bitva za Sevastopol' (Battle for Sevastopol), 2015.

${ }^{45}$ Zhenshchina-snaiper sovetovala federalam "berech organy" (Woman-snipers advised Russian Federation soldiers to "protect their parts"). RBK News, March 31, 2001. Available at http://top.rbc.ru/incidents/31/03/2001/42987.shtml, last accessed on June 13, 2017.

${ }^{46}$ Opolchenets: Zhenshchiny-snaipery u aeroporta v Donetske streliali nashim v pakh (Militiaman: Women-snipers around Donetsk airport aimed at our groins). Life.ru, May 31, 2014. Available at http://lifenews.ru/news/134208, last accessed on June 12, 2017.

${ }^{47}$ See the online dictionary at http://www.russki-mat.net/page.php?l=RuFr\&a=\%D0\%94, last accessed on June 13, 2017.

${ }^{48}$ English translation of the tales from https://russian-crafts.com/tales.html, last accessed on June 13, 2017.

${ }^{49}$ Human Rights violations in the Chechen conflict between autumn 1999 and February 2000. Report by the Organisation of Soldiers' Mothers of St. Petersburg to the April 2000 session of the Parliamentary Assembly of the Council of Europe (personal archives).

${ }^{50}$ See, for example, the story about the Russian sniper Anna (Snaipersha Anna: Moloduiu moskvichku obuchali ubivat' rossiiskikh soldat v lagere Khattaba (Sniper Anna: How a young Moscow girl learnt to kill Russian soldiers in Khattab camps). Komsomolskaia Pravda, August 9, 2001 (available at http://www.kp.ru/daily/22608/9606/) or about a Leningrad biathlonist (Olga Dobromyslova: Missiia nevypolnima (Mission Impossible). Rossiiskaia Gazeta, December 16, 2005 (available at http://www.rg.ru/2005/12/16/ chechnya.html), both last accessed on June 14, 2017. 


\section{REFERENCES}

Allport, Gordon W. \& Postman, Leo J. 1947. The Psychology of Rumor. New York: H. Holt and Co.

Astashkin, Nikolai 2003. I snova vzryvy, snova zhertvy... [Again Explosions, Again Victims...] Krasnaia Zvezda, May 21. Available at http://old.redstar. ru/2003/05/21_05/1_03.html, last accessed on June 2, 2017.

Azar 2016 = Azar, Il'ia. "Ia ee vzial i lichno peredal Plotnitskomu": Boets LNR rasskazal 'Meduze', kak zaderzhivali Nadezhdu Savchenko. [Fighter of the LNR told Medusa how Nadezhda Savchenko Was Arrested.] Meduza, March 21. Available at https://meduza.io/feature/2016/03/21/ya-ee-vzyal-i-lichno-peredal-plotnitskomu, last accessed on June 1, 2017.

Babchenko, Arkady 2016. Pokhishchennaia: Konets sudebnogo predstavleniia i nachalo torgovli. [Abducted: End of Court Performance and Beginning of a Business Transaction.] Spektr, March 22. Available at http://spektr.press/pohischennayakonec-sudebnogo-predstavleniya-i-nachalo-torgovli/, last accessed on May 31, 2017.

Baky, John S. 1994. White Cong and Black Clap: The Ambient Truth of Vietnam War Legendry. Viet Nam Generation: A Journal of Recent History and Contemporary Issues, Vol. 5, Nos. 1-4. Available at http://www2.iath.virginia.edu/sixties/HTML_ docs/Texts/Scholarly/Baky_White_Cong_01.html, last accessed on June 14, 2017.

Barden, Thomas E. \& Provo, John 1995. Legends of the American Soldiers in the Vietnam War. Fabula, Vol. 36, No. 3-4, pp. 217-229. http://dx.doi.org/10.1515/ fabl.1995.36.3-4.217.

Beevor, Antony 2009. D-Day et la bataille de Normandie. Transl. by J.-F. Sené \& R. Clarinard \& I. Taudière. Paris: Calmann-Lévy.

Begunova, Alla 2014. Angely Smerti: Zhenshchiny-snaipery, 1941-1945. [Angels of Death: Women-Snipers, 1941-1945.] Moscow: Veche.

Belibentsev, Dmitri 2006. Skorpiony protiv Belykh kolgotok. [Scorpions against White Tights.] Sovetskaia Chuvashia, June 27. Available at http://www.memo.ru/hr/ hotpoints/caucas1/msg/2006/06/m70558.htm, last accessed on June 13, 2017.

Bennett, Gillian 2005. Bodies: Sex, Violence, Disease, and Death in Contemporary Legend. Jackson: University Press of Mississippi.

Bennett, Gillian \& Smith, Paul (eds.) 1996. Contemporary Legend: A Reader. New York \& London: Garland Publishing.

Bloch, Marc 1999 [1921]. Réflexions d'un historien sur les fausses nouvelles de la guerre. Paris: Allia.

Bonaparte, Marie 1946. Mythes de guerre. Paris: PUF.

Bonhomme, Julien 2009. Les Voleurs de sexe: Anthropologie d'une rumeur africaine. Paris: Seuil.

Bourke, Joanna 1999. An Intimate History of Killing: Face-to-Face Killing in Twentieth Century Warfare. New York: Basic Books.

Campion-Vincent, Véronique \& Renard, Jean-Bruno 2002. De Source sûre: Nouvelles rumeurs d'aujourd'hui. Paris: Payot. 
Chapai, Artem 2015. Sluzhili dva “aidarovtsa”: O chem priniato molchat' na voine. [Two Aidar Members Served: What Is Not Talked About in the War.] The Insider, January 5. Available at http://www.theinsider.ua/politics/54a9af9fa9f76/, last accessed on June 14, 2017.

Collins, Randall 2009. Violence: A Micro-Sociological Theory. Princeton \& Oxford: Princeton University Press.

Dargo, Abdulla 1999. "Belye kolgotki” voevali v Dagestane. ["White Tights" Fought in Dagestan.] Nezavisimaia Gazeta, October 2. Available at http://www.ng.ru/ events/1999-10-02/stocking.html, last accessed on June 1, 2017.

Dégh, Linda 1991. What Is the Legend After All? Contemporary Legend, Vol. 1, pp. 11-38.

Dégh Linda 1996. What is a Belief Legend? Folklore, Vol. 107, pp. 33-46. Available at https://www.jstor.org/stable/1260912?seq=1\#page_scan_tab_contents, last accessed on June 14, 2017.

Dégh, Linda \& Vázsonyi, Andrew 1983. Does the Word "Dog” Bite? Ostensive Action: A Means of Legend-Telling. Journal of Folklore Research, Vol. 20, No. 1, pp. 5-34. Available at https://www.jstor.org/stable/3814298?seq=1\#page_scan_tab_ contents, last accessed on June 14, 2017.

Denber, Rachel 2014. Dispatches: Leaked Call, But Where's the Truth in Ukraine? Human Rights Watch, March 6. Available at http://www.hrw.org/news/2014/03/05/ dispatches-leaked-call-where-s-truth-ukraine, last accessed on June 12, 2017.

FIDH/CCL 2015 = Eastern Ukraine: Civilians Caught in the Crossfire. FIDH Center of Civil Liberties, No. 667a. Available at https://www.fidh.org/IMG/pdf/eastern ukraine-ld.pdf, last accessed on June 14, 2017.

Fine, Gary Alan \& Campion-Vincent, Véronique \& Heath, Chip (eds.) 2005. Rumor Mills: The Social Impact of Rumor and Legend. New Brunswick \& London: Aldine Transaction.

Fine, Gary Alan \& Ellis, Bill 2010. The Global Grapevine: Why Rumors of Terrorism, Immigration, and Trade Matter. New York: Oxford University Press.

Freytag, Claudia 2002. Kriegsbeute 'Flintenweib' Rotarmistinnen in deutscher Gefangenschaft. In: Swetlana Alexejewitsch (ed.) Mascha, Nina, Katjuscha: Frauen in der Roten Armee 1941-1945. Berlin: Links Verlag, pp. 32-36.

Gulzow, Monte \& Mitchel, Carol 1980. 'Vagina Dentata' and 'Incurable Venereal Disease': Legends from the Vietnam War. Western Folklore, Vol. 39, No. 4, pp. 306-316.

Héritier, Françoise 1996. Masculin / Féminin: La pensée de la difference. Paris: Odile Jacob.

Hohmann, Sophie 2015. Violence domestique dans le Caucase du Sud: Les exemples de l'Arménie et de l'Azerbaidjan. Revue d'études comparatives Est-Ouest, Vol. 46, No. 2, pp. 105-142. Available at https://receo.revues.org/1941, last accessed on June 15, 2017.

Horne, John \& Kramer, Alan 2001. German Atrocities, 1914: A History of Denial. New Haven, Conn.: Yale University Press.

Ianchenkov, Vladimir 2000. Dikie gusyni v belykh kolgotkakh. [Wild Geese in White Tights.] Trud, April 1. Available at http://www.trud.ru/article/01-04-2000/4238_ dikie_gusyni_v_belyx_kolgotkax.html, last accessed on May 31, 2017. 
Keneally, Meghan 2011. Taking on the Taboos: Vintage STD Posters Show How Patriotism and Prostitutes Played a Role in Postwartime Ad Campaign. Daily Mail, November 22. Available on http://www.dailymail.co.uk/news/ article-2064941/Vintage-STD-posters-Patriotism-prostitutes-played-role-postWWII-ad-campaign.html, last accessed on June 13, 2017.

Krylov, Aleksandr 1999. Suchka. [Bitch.] Available at http://alexanderterski.narod.ru/ songsres.files/suchka.htm, last accessed on June 13, 2017.

Langenhove, Fernand van 1916. Comment naît un cycle de legends: Francs-tireurs et atrocités en Belgique. Lausanne \& Paris: Payot. Available at http://www.archive. org/stream/commentnatuncy00languoft, last accessed on June 15, 2017.

Le Naour, Jean-Yves 2007. 'Mon flingot c'est cupidon', la sexualité du soldat. In: François Rouquet \& Fabrice Virgili \& Danièle Voldman (eds.) Amours, guerres et sexualité: 1914-1945. Paris: Gallimard / BDIC / Musée de l'armée.

Likhomanov, Petr 2014. Sport nizkikh dostizhenii. [Sport with Low Achievements.] Rossiiskaia Gazeta, June 3. Available at http://www.rg.ru/2014/06/02/ukrainkasite.html, last accessed on June 1, 2017.

Maetnaia, Elizaveta 2001. Volchitsy v belykh kolgotkah. [She-Wolves in White Tights.] Moskovskii Komsomolets, April 6. Available on http://www.memo.ru/hr/ hotpoints/N-Caucas/ch99/010406/mk0406a.htm, last accessed on June 13, 2017.

Maksakov, Vladimir 2014. 22 dnia v DNR. [22 Days in the DNR.] Colta.ru, November 11. Available at http://www.colta.ru/articles/society/5329, last accessed on June 2, 2017.

Medvedev, Evgeni n.d. Krovavoe leto v Benderakh. [Bloody Summer in Bendery.] Available at http://artofwar.ru/k/kazakow_a_m/text_0290.shtml, last accessed on June 13, 2017.

Melnikov, Ruslan 2014. Pimpochki dlia avtomata. [This Thingummy for a Machine Gun.] Rossiiskaia Gazeta, June 2, No. 6394. Available at http://www.rg.ru/2014/06/01/ batalyon-site.html, last accessed on June 13, 2017.

Oring, Elliott 1990. Legend, Truth, and News. Southern Folklore, Vol. 47, No. 2, pp. 163 177.

Oring, Elliott 2008. Legendry and the Rhetoric of Truth. Journal of American Folklore, Vol. 121, No. 480, pp. 127-166. Available at http://www.jstor.org/stable/20487594, last accessed on June 15, 2017.

Ponsonby, Arthur 1928. Falsehood in War-time: Propaganda Lies of the First World War. N.p.: George Allen and Unwin. Available at http://www.vlib.us/wwi/resources/ archives/texts/t050824i/ponsonby.html, last accessed on July 10, 2017.

Rasskazov 2001 = Rasskazov, Evgenii. Zima: maskirovat'sia, chtoby vyzhit'. [Winter: Camouflage to Stay Alive.] Sinopa, No. 1. Available at http://www.sinopa.ee/ kalashnikov/k2001/k0101/k010152/k010152.htm, last accessed on June 2, 2017.

Regamey, Amandine 2008. L'opinion publique russe et l'affaire Boudanov. The Journal of Power Institutions in Post-Soviet Societies, Vol. 8. Available at http://www. pipss.org/document1493.html, last accessed on June 15, 2017.

Regamey, Amandine 2011. Les femmes snipers de Tchétchénie: Interprétations d'une légende de guerre. Questions de Recherche / Research in Question, No. 35. Available at http://www.sciencespo.fr/ceri/sites/sciencespo.fr.ceri/files/qdr35.pdf, last accessed on June 15, 2017. 
Regamey, Amandine 2012a. The Weight of Imagination: Rapes and the Legend of Women Snipers in Chechnya. In: R. Branche \& F. Virgili (eds.) Rape in Wartime. London: Palgrave MacMillan, pp. 128-139. DOI: 10.1057/9781137283399.

Regamey, Amandine 2012b. Comparing Violence: Organ Theft Rumors in Chechnya and South America. Laboratorium, Vol. 3, pp. 42-66. Available at http://soclabo.org/ index.php/laboratorium/article/view/49, last accessed on June 15, 2017.

Rogozin, Dmitri 2010. Iastreby mira: Dneunik russkogo posla. [Hawks of the World: Diary of a Russian Ambassador.] Moscow: ANF. Available at http://lib.rus.ec/b/246440/ read, last accessed on June 12, 2017.

Romashov, Georgy 1995. Naemniki v Chechne: On khatu pokinul, poshel voevat'.... [Mercenaries in Chechnya.] Kommersant, No. 7, January 18. Available at http:// www.kommersant.ru/doc.aspx?DocsID=99614, last accessed on June 1, 2017.

Shcherbakov, Sergei n.d. Fatima. Available at http://artofwar.ru/s/sherbakow_s_a/ fatimadoc.shtml, last accessed on June 1, 2017.

Scheper-Hughes, Nancy 1996. Theft of Life: The Globalization of Organ Stealing Rumours. Anthropology Today, Vol. 12, No. 3, pp. 3-11. DOI: 10.2307/2783143.

Semelin, Jacques 2002. Analyser le massacre: Réflexions comparatives. Questions de Recherche / Research in Question, No. 7. Available at http://www.sciencespo.fr/ ceri/sites/sciencespo.fr.ceri/files/qdr7.pdf, last accessed on June 15, 2017.

Sieca-Kozlowski, Elisabeth 2008. Les liens indéfectibles entre la société et l'armée en Russie post-soviétique. In: Anne Le Huérou \& Elisabeth Sieca-Kozlowski (eds.) Culture militaire et patriotisme dans la Russie d'aujourd'hui. Paris: Karthala, pp. $147-170$.

Theweleit, Klaus 1987. Male Fantasies, Volume 1: Women, Floods, Bodies, History. Minneapolis: University of Minnesota Press.

Troshev, Gennadi 2001. Moia Voina: Chechenskii dnevnik okopnogo generala. [My War: Diary of a General in the Trenches.] Moscow: Vagrius. Available at http://www. soldat.ru/memories/troshev, last accessed on July 11, 2017.

Voronov, Vladimir 2004. Lubianskii Pul. [The Journalist Pool on Lubianka Square.] Index, Vol. 20. Available at http://www.index.org.ru/journal/20/voronov20.html, last accessed on May 31, 2017.

White, Luise 2000. Speaking with Vampires: Rumor and History in Colonial Africa. Berkeley \& Los Angeles \& London: University of California Press. Available at http://publishing.cdlib.org/ucpressebooks/view?docId=ft8r29p2ss\&brand=ucpre ss, last accessed on June 15, 2017. 